\title{
Deficiency of Protein 4.2 in Erythrocytes from a Patient with a Coombs Negative Hemolytic Anemia

\author{
Evidence for a Role of Protein 4.2 in Stabilizing Ankyrin on the Membrane
}

\author{
Anne C. Rybicki," Russell Heath," Jeffrey L. Wolf, ${ }^{\ddagger}$ Bertram Lubin, ${ }^{*}$ and Robert S. Schwartz*5 \\ ${ }^{*}$ Childrens Hospital-Oakland Research Institute, Oakland, California 94609; and ${ }^{\ddagger}$ Alta Bates Hospital, Department of Medical \\ Oncology, Hematology and Bone Marrow Transplantation, Berkeley, California 94705
}

\begin{abstract}
A patient with a mild hemolytic anemia and osmotically fragile, spherocytic erythrocytes was studied. Analysis of the erythrocyte membrane proteins by SDS-PAGE revealed a deficiency of protein 4.2 ( $<0.10 \%$ of normal). The protein 4.2 deficient erythrocytes contained normal amounts of all other membrane proteins, although the amount of band 3 was slightly reduced and the amount of band 6 (G3PD) was slightly elevated. The spectrin content of these cells was normal, as measured by both SDS-PAGE and radioimmunoassay. Erythrocytes from the patient's biologic parents were hematologically normal and contained normal amounts of protein 4.2 . Immunological analysis using affinity purified antibodies revealed that the patient's protein 4.2 was composed of equal amounts of a 74-kD and 72-kD protein doublet, whereas the normal protein was composed primarily of a 72-kD monomer. Proteolytic digestion studies using trypsin, $\alpha$-chymotrypsin and papain demonstrated that the patient's protein 4.2 was similar but not identical to the normal protein. Binding studies showed that the protein 4.2-deficient membranes bound purified protein 4.2 to the same extent as normal membranes, suggesting that the membrane binding site(s) for the protein were normal. Depleting the protein 4.2-deficient membranes of spectrin and actin resulted in a loss of nearly two-thirds of the membrane ankyrin, whereas similar depletion of normal membranes resulted in no loss of ankyrin. Repletion of the protein 4.2-deficient membranes with purified protein 4.2 before spectrin-actin extraction partially prevented the loss of ankyrin. These results suggest that protein 4.2 may function to stabilize ankyrin on the erythrocyte membrane.
\end{abstract}

\section{Introduction}

A major determinant of erythrocyte membrane shape and stability is the membrane cytoskeleton, a two-dimensional protein lattice located on the inner surface of the cell membrane. It is composed of two major supporting proteins, spectrin and actin; two linking proteins, ankyrin and protein 4.1; and their respective attachment sites on the cytoplasmic poles of band 3 and glycophorin (1). Defects or deficiencies in the protein

Dr. Schwartz' present address is Albert Einstein College of Medicine/ Montefiore Hospital Medical Center, Department of Hematology, Central 221, 111 East 210th Street, Bronx, NY 10467. Please address reprint requests to him.

Received for publication 5 June 1987 and in revised form 19 October 1987.

J. Clin. Invest.

(c) The American Society for Clinical Investigation, Inc.

0021-9738/88/03/0893/09 \$2.00

Volume 81, March 1988, 893-901 composition of the membrane cytoskeleton, or in the proteins that link the cytoskeleton to the membrane bilayer, usually result in abnormal erythrocyte morphologies and mild to severe hemolytic anemias. Genetic mutations in spectrin and protein 4.1 have been reported (2-5) and are associated with the hemolytic anemias hereditary spherocytosis (HS) ${ }^{1}$ and hereditary elliptocytosis (HE). The present work examines a hematological disorder in which the erythrocytes are morphologically abnormal (spherocytic and elliptocytic), osmotically fragile and less deformable than normal erythrocytes. Unlike erythrocytes from patients with $\mathrm{HS}$ or $\mathrm{HE}$, however, the protein abnormality observed in this patient's erythrocytes is a deficiency of protein 4.2.

Protein 4.2 is a $72-\mathrm{kD}$ peripheral membrane protein which represents $\sim 5 \%$ of total membrane protein and is the last major erythrocyte membrane protein to remain uncharacterized. It is known to bind to the cytoplasmic pole of band 3 (6), and crosslinking studies have suggested that it is probably a tetramer both on the membrane and in solution (7). Other studies, in which membrane extracts containing band 3, protein 4.2 and ankyrin bound as a complex to an anti-ankyrin affinity column, suggested that these proteins may be associated in the membrane (8).

In the current study, we have demonstrated that a protein 4.2 deficiency is associated with abnormalities in erythrocyte shape and membrane stability. Although the protein 4.2-deficient ghost membranes contained a normal amount of ankyrin, membrane vesicles produced by low ionic strength extraction contained less ankyrin than normal membranes indicating a weakened interaction of ankyrin with the spectrin-depleted protein 4.2-deficient membrane. This abnormal ankyrin-membrane interaction could be partially corrected by reconstituting purified protein 4.2 into the protein 4.2-deficient ghost membranes. We suggest that this abnormal ankyrin-membrane interaction in the protein 4.2-deficient erythrocytes may be responsible for some of the membrane defects observed at the cellular level.

\section{Methods}

Clinical studies. After obtaining informed consent, venous blood was drawn from the patient, the patient's biologic parents and normal control subjects. Routine hematological parameters were determined on an automated cell counter (Coulter model S Plus; Coulter Electronics, Hialeah, FL).

Reticulocyte counts were performed after new methylene blue staining (9). Osmotic fragility studies were performed on heparinized

1. Abbreviations used in this paper: DFP, diisopropylfluorophosphate; G3PD, glyceraldehyde-3-phosphate dehydrogenase; HE, hereditary elliptocytosis; HPP, hereditary pyropoikilocytosis; HS, hereditary spherocytosis; IOVs, inside-out vesicles; SEM, scanning electron microscopy. 
blood after sterile incubation for $24 \mathrm{~h}$ at $37^{\circ} \mathrm{C}$ by the method of Dacie (9).

Morphologic studies. Fixation of erythrocytes for study by scanning electron microscopy (SEM) was carried out by mixing anticoagulated whole blood with a 10 -fold volume of $1 \%$ glutaraldehyde, $100 \mathrm{mM} \mathrm{Na}$ cacodylate, $\mathrm{pH} 7.4$, for $2 \mathrm{~h}$ at $25^{\circ} \mathrm{C}$. After removal of the fixative, the cells were washed three times with $20 \mathrm{vol}$ of $50 \mathrm{mM} \mathrm{Na}$ cacodylate, 250 $\mathrm{mM}$ sucrose and added to $20 \mathrm{vol}$ of $1 \%$ osmium tetroxide, $50 \mathrm{mM} \mathrm{Na}$ cacodylate, $212 \mathrm{mM}$ sucrose for $2 \mathrm{~h}$ at $25^{\circ} \mathrm{C}$ with gentle mixing. The fixed cells were then washed five times with $60 \mathrm{vol}$ of distilled water $\left(\mathrm{dH}_{2} \mathrm{O}\right)$, resuspended in $60 \mathrm{vol} \mathrm{dH}_{2} \mathrm{O}$, and stored at $4^{\circ} \mathrm{C}$ until scanned. For scanning, one drop of fixed cells was applied to a microscope cover slip and allowed to settle for $1 \mathrm{~h}$. Excess $\mathrm{dH}_{2} \mathrm{O}$ was removed with filter paper, the samples allowed to air dry, a thin film $(20 \mathrm{~nm})$ of gold was deposited on the surface of the cells and they were examined in an AMR-1000A scanning electron microscope at $10 \mathrm{kV}$.

Membrane deformability studies (osmotic gradient ektacytometry). Whole red cell deformability was measured as a continuous function of the suspending medium osmolality using an ektacytometer (Technicon Instruments, Tarrytown, NY) (10). Cell deformability is expressed as a deformability index which is equivalent to the ellipticity of the deformed cells.

Membrane lipid analysis. Membrane lipid extraction was performed according to the method of Rose and Oklander (11). Cholesterol was determined according to Zlatkis et al. (12) and phospholipid was determined as inorganic phosphorus (13).

Preparation of erythrocyte ghosts and membrane vesicles. Erythrocyte ghosts were prepared from freshly drawn blood anticoagulated in acid citrate/dextrose by the hypotonic lysis procedure of Dodge et al. (14) except that $0.4 \mathrm{mM}$ diisopropylfluorophosphate (DFP) was added at the lysis step. Spectrin and actin depleted inside-out vesicles (IOVs) were prepared by the method of Bennett and Branton (15), with some modifications; ghost membranes were incubated in $0.1 \mathrm{mM} \mathrm{Tris} / \mathrm{HCl}$, $\mathrm{pH} 8.0$, at $37^{\circ} \mathrm{C}$ for $30 \mathrm{~min}$ to induce membrane vesiculation. Protein 4.1- and ankyrin-depleted IOVs were prepared by the method of Hargreaves et al. (16).

Preparation of antiserum. Monospecific antibodies against human erythrocyte spectrin were purchased from Miles Laboratories (Naperville, IL). Anti-ankyrin IgG was made by immunizing rabbits with human erythrocyte ankyrin purified by the method of Tyler et al. (17). Anti-protein $4.2 \mathrm{IgG}$ was made by electroeluting protein 4.2 from polyacrylamide gels on which proteins from $\mathrm{pH} 11.0$ extracts of IOVs were separated, and then immunizing rabbits with the electroeluted protein by standard immunization techniques. The anti-protein 4.2 IgG was affinity purified on Affi-gel 10 (Bio-Rad Laboratories, Richmond, CA) that had been coupled to erythrocyte membrane pH 11.0 extracts.

Gel electrophoresis and immunoblotting. SDS-PAGE was performed utilizing either the discontinuous buffer system of Laemmli (18), or when ankyrin was to be quantitated, the continuous buffer system of Fairbanks et al. (19). The proteins were stained with Coomassie Brilliant Blue, and after destaining the gels were scanned using a laser densitometer (LKB model 2222; LKB Instruments, Inc., Gaithersburg, MD) with GSXL/1D software. For immunoblotting purposes, the proteins were transferred to nitrocellulose according to the procedure of Towbin et al. (20) and the immunoblots developed with horseradish peroxidase (HRP)-conjugated second antibody and HRP substrate (Bio-Rad Laboratories).

Limited proteolytic digestion of vesicle membranes. Normal and patient spectrin-depleted IOV membranes were prepared as described above (15). Vesicle membranes $(150 \mu \mathrm{g})$ were then incubated with $1 \mu \mathrm{g}$ trypsin, $1 \mu \mathrm{g} \alpha$-chymotrypsin or $0.33 \mu \mathrm{g}$ papain (total volume $0.1 \mathrm{ml}$ ) for $1 \mathrm{~h}$ at $4^{\circ} \mathrm{C}$. The reaction was terminated by the addition of the Laemmli solubilization buffer (18) and boiling for $2 \mathrm{~min}$. Aliquots were then analyzed by SDS-PAGE (7.5 $\mu \mathrm{g}$ normal, $150 \mu \mathrm{g}$ patient) and immunoblotting using anti-protein 4.2 IgG.

Spectrin radioimmunoassay. Spectrin RIA was performed as described by Agre et al. (2).
Purification of protein 4.2. Protein 4.2 was purified according to the method of Korsgren and Cohen (21), with some modifications. Spectrin-depleted IOVs were prepared by incubating ghost membranes in $30 \mathrm{vol}$ of $0.1 \mathrm{mM} \mathrm{EGTA,} \mathrm{pH} 8.5$, at $37^{\circ} \mathrm{C}$ for $30 \mathrm{~min}$. Ankyrin, protein 4.1 and glyceraldehyde-3-phosphate dehydrogenase (G3PD) were extracted from IOVs by incubation in $1 \mathrm{M} \mathrm{KCl}$ at $37^{\circ} \mathrm{C}$ for $30 \mathrm{~min}$, and protein 4.2 along with any residual ankyrin and protein 4.1 was extracted by incubation in $0.1 \mathrm{mM}$ EDTA, $\mathrm{pH} 11.0$, for $45 \mathrm{~min}$ at $37^{\circ} \mathrm{C}$. To purify protein 4.2 , the $\mathrm{pH} 11.0$ extract, immediately neutralized to pH 8.0, was applied to a Sephacryl S-200 gel filtration column (2.5 $\times 65 \mathrm{~cm}$ ) equilibrated in $5 \mathrm{mM}$ sodium phosphate, $\mathrm{pH} 8.0$, containing $1 \mathrm{M}$ potassium iodide, $0.5 \mathrm{mM}$ EGTA, and $0.5 \mathrm{mM}$ DTT. For reassociation studies, purified protein 4.2 was radioiodinated using the Bolton Hunter Reagent (22).

Preparation of protein 4.2-depleted IOVs. Protein 4.2-depleted IOV membranes were prepared by adding the $1 \mathrm{M} \mathrm{KCl}$ extracted membranes described above to $30 \mathrm{vol}$ of $0.1 \mathrm{mM}$ EGTA, $\mathrm{pH} 11.0$ and incubating at $37^{\circ} \mathrm{C}$ for $45 \mathrm{~min}$. The protein 4.2 -depleted IOVs were collected by centrifugation, immediately brought to $\mathrm{pH} 8.0$, and then dialyzed vs. $5 \mathrm{mM}$ sodium phosphate, $0.1 \mathrm{mM}$ EGTA, pH 8.0, as described by Korsgren and Cohen (21).

Protein 4.2 membrane binding assay. Binding of ${ }^{125}$ I-protein 4.2 to pH 11.0 stripped (protein 4.2-depleted) IOVs was measured according to the method of Korsgren and Cohen (21), with some modifications. The pH 11.0 stripped IOVs had $<10 \%$ of the normal amount of protein 4.2 and were essentially composed of only band 3 . In our hands, we found that a considerable amount of nonspecific binding of purified protein 4.2 to tube surfaces occurred (65\% of total binding), therefore, the iodinated protein 4.2 was routinely precentrifuged at $40,000 \mathrm{~g}$ for $30 \mathrm{~min}$ at $4^{\circ} \mathrm{C}$ immediately before use in the binding assay. This pre-spin resulted in $<10 \%$ nonspecific protein binding. The protein concentration of $\mathrm{pH} 11.0$ stripped IOVs was often variable by dye binding protein determinations, therefore, IOVs were solubilized in $1 \%$ SDS and protein measured at $280 \mathrm{~nm}$. Various concentrations of purified protein $4.2(0-140 \mu \mathrm{g} / \mathrm{ml})$ were incubated in duplicate with pH 11.0 stripped IOVs $(20 \mu \mathrm{g})$ in $120 \mathrm{mM} \mathrm{KCl}, 5 \mathrm{mM}$ sodium phosphate, pH 8.0, $0.5 \mathrm{mM}$ EGTA, $0.5 \mathrm{mM}$ DTT, $1 \mathrm{mg} / \mathrm{ml} \mathrm{BSA}$, $0.02 \% \mathrm{NaN}_{3}$ (reassociation buffer) in a total volume of $0.2 \mathrm{ml}$ for $18 \mathrm{~h}$ at $4^{\circ} \mathrm{C}$. The mixtures were then centrifuged in a $42.2 \mathrm{Ti}$ rotor at 20,000 rpm for $30 \mathrm{~min}$ at $4^{\circ} \mathrm{C}$ in an ultracentrifuge (model L8-80; Beckman Industries, Palo Alto, CA). After removal of the supernatants, the IOVs were washed once in reassociation buffer and counted. Control experiments without IOVs were similarly performed for each protein 4.2 concentration tested and nonspecific binding of protein 4.2 was subtracted from the experimental values. Duplicate values varied by no more than $5 \%$. Binding curves were additionally analyzed by the method of Scatchard (23).

Preparation of protein 4.2-reassociated erythrocyte membranes. Erythrocyte ghost membranes and protein 4.2, prepared as described above, were equilibrated in $5 \mathrm{mM}$ sodium phosphate, $\mathrm{pH}$ 8.0. Leaky ghost membranes $(165 \mu \mathrm{g})$ were incubated with purified protein 4.2 (35 $\mu \mathrm{g}$ ) in a total volume of $1.0 \mathrm{ml} 5 \mathrm{mM}$ sodium phosphate, $\mathrm{pH} 8.0,0.5$ mM EGTA, $0.5 \mathrm{mM}$ DTT, $0.02 \% \mathrm{NaN}_{3}$, and $1 \mu \mathrm{g} / \mathrm{ml}$ leupeptin, for 3 $\mathrm{h}$ at $4^{\circ} \mathrm{C}$. At the end of $3 \mathrm{~h}, 120 \mathrm{mM} \mathrm{KCl}$ was added to induce ghost resealing and protein 4.2 binding (21) and the incubation continued for an additional $15 \mathrm{~h}$ at $4^{\circ} \mathrm{C}$. At the end of the incubation, the ghosts were collected by centrifugation, washed, and spectrin-depleted IOVs prepared from the resealed ghosts, as described above.

\section{Results}

Morphological and clinical studies. The patient is a 26-yr-old Japanese-American female who was followed over a period of 2 yr. She presented with a mild Coombs negative hemolytic anemia (Hgb $10.9 \mathrm{~g} / \mathrm{dl}, 8 \%$ reticulocytes) with most of the erythrocytes exhibiting a spherocytic shape along with 5-10\% 
elliptocytes (Table I and Fig. 1). Erythrocyte osmotic fragility was increased ( $50 \%$ of the cells lysed at $0.65-0.67 \% \mathrm{NaCl}$ compared with $0.5 \% \mathrm{NaCl}$ for normal cells). Erythrocytes from the patient's biologic parents were also tested and all hematological parameters were normal. The patient was splenectomized $\sim 6$ mo after our initial studies were performed that corrected the anemia (Hgb $12.7 \mathrm{~g} / \mathrm{dl}$, reticulocytes $<1 \%$ ) although the abnormal erythrocyte morphology and osmotic fragility persisted.

Patient erythrocyte membranes are less deformable. The membrane deformability profile as measured by ektacytometry was abnormal in the patient as compared to controls (Fig. 2 ). The reduction in the maximally attained deformability index (maximal height of the curve) is indicative of a reduced membrane surface area, and the shift to the right of the deformability minimum in the hypotonic range (100-200 mos$\mathrm{mol} / \mathrm{kg}$ ) is indicative of a reduced surface area to volume ratio. This pattern is similar to those observed with erythrocytes from patients with iron deficiency or mild HS. The patient in our study was not found to be iron deficient (free erythrocyte protoporphyrin was $59 \mathrm{~g} / \mathrm{dl}$ ). Patients with typical HS whose erythrocytes are dehydrated usually show an altered profile in the hypertonic range of the ektacytometer scan, whereas the patient in our study was normal in this regard. The ektacytometric scans of the patient's parents were normal.

The loss of membrane surface area in the patient's erythrocytes indicated by the ektacytometric scans was confirmed by direct lipid measurements (Table II). Both the cholesterol and phospholipid content of the patient's erythrocytes were below normal ( $3.4 \mathrm{mM}$ and $4.0 \mathrm{mM}$, respectively), and the cholesterol/phospholipid ratio (C/PL ratio) was slightly decreased $(C / P L=0.86)$ due to a relative smaller cholesterol content compared to phospholipid content. The decreased $\mathrm{C} / \mathrm{PL}$ ratio of the patient's erythrocytes persisted postsplenectomy (C/PL $=0.85$ ).

Protein composition of patient erythrocyte membranes. Analysis of patient ghost membrane proteins by SDS-PAGE revealed that the patient membranes were $>90 \%$ deficient in protein 4.2 (Fig. 3 and Table III). This is not the result of

Table I. Hematological Parameters from a Patient with Protein 4.2-Deficient Erythrocytes*

\begin{tabular}{lccc}
\hline & $\begin{array}{c}\text { Normal } \\
\text { range }\end{array}$ & $\begin{array}{c}\text { Presplenectomized } \\
\text { patient }\end{array}$ & $\begin{array}{c}\text { Postsplenectomized } \\
\text { patient }\end{array}$ \\
\hline RBC $\left(10^{6} / \mu l\right)$ & $4-5.6$ & 3.66 & 4.47 \\
HGB $(g / d l)$ & $12-16$ & 10.9 & 12.7 \\
HCT $(\%)$ & $37-47$ & 31.6 & 37.8 \\
MCV $(f l)$ & $80-100$ & 86.4 & 84.6 \\
MCH $(p g)$ & $27-33$ & 29.8 & 28.4 \\
MCHC $(g / d l)$ & $32-36$ & 34.5 & 33.6 \\
Osmotic fragility & 0.5 & 0.65 & 0.67 \\
$\quad \%$ NaCl for $50 \%$ & & & \\
hemolysis) & & & \\
Reticulocytes $(\%)$ & $<1$ & 8 & 0.9 \\
FEP $(g / d l)$ & $<90$ & 59 & ND \\
RDW $(\%)$ & $12-14$ & 16.4 & 16.5 \\
& & & \\
\hline
\end{tabular}

* All values except FEP and reticulocytes were from the Coulter model S plus automated cell counter. FEP, free erythrocyte protoporphyrin. RDW, red cell distribution width. ND, not determined. excessive proteolysis of the membrane proteins during handling since both patient and normal blood samples were drawn at the same time and handled identically. We were also careful to use chilled buffers and include protease inhibitors during all preparative procedures. In addition to the absence of protein 4.2, the patient's membranes had a statistically significant decrease in the amount of band 3 and an elevated amount of band 6 (G3PD). The deficiency of protein 4.2, decreased content of band 3 and increased content of band 6 persisted postsplenectomy. To rule out the possibility that the abnormal cell morphology, osmotic fragility and deformability of the patient's erythrocytes was due to a small decrease in the amount of spectrin that might not be detected by electrophoretic analysis, total erythrocyte spectrin was measured by radioimmunoassay, as described by Agre et al. (2). As shown in Fig. 4, the patient's erythrocytes had normal amounts of spectrin. Electrophoretic analysis of erythrocyte ghost membranes from both of the patient's biologic parents revealed a normal content of all membrane proteins (data not shown).

To rule out the possibility that the patient's erythrocytes contained protein 4.2 in the cell cytosol instead of attached to the membrane, we solubilized whole erythrocytes in 5\% SDS and analyzed the solubilized proteins by SDS-PAGE. Whereas protein 4.2 was detected in normal solubilized erythrocytes, we did not detect protein 4.2 in the patient's solubilized erythrocytes (data not shown).

Patient erythrocyte membranes contain a small amount of immunoreactive protein 4.2. When SDS-PAGE-separated patient ghost membranes were further analyzed by immunoblotting with affinity purified anti-protein $4.2 \mathrm{IgG}$, a small amount of an immunoreactive protein 4.2 analogue was observed ( $<10 \%$ of normal protein 4.2$)$. This protein 4.2 variant differed from the normal protein in that it was composed of equal amounts of a protein doublet ( 74 and $72 \mathrm{kD}$ ), whereas the normal protein was composed primarily of a single molecular species of $72 \mathrm{kD}$ (Fig. 5). The binding of the protein 4.2 variant to its membrane binding site(s) appeared to be normal since it could only be removed from the membrane by using relatively harsh conditions ( $\mathrm{pH} 11.0)$, similar to the case for the normal protein.

Limited proteolytic digestion patterns of normal and patient protein 4.2 are similar but not identical. To determine if the patient's protein 4.2 variant was molecularly similar to the normal protein, IOVs prepared from patient and normal erythrocytes were partially digested with proteases (trypsin, $\alpha$-chymotrypsin, and papain) and the peptides generated were analyzed by SDS-PAGE combined with immunoblotting using anti-protein $4.2 \mathrm{IgG}$ (Fig. 6). Using these three proteases, patient protein 4.2 digests contained most of the protein bands corresponding to the major bands in the normal digests. However, some differences were apparent, most notably in the $\alpha$ chymotrypsin and papain digests where the normal digests contained at least one major protein band not seen in the patient digests. Furthermore, many of the protein bands in the patient digests were doublets, which were most likely related to the protein doublet observed in the undigested patient protein. These results suggest that the normal protein and patient protein 4.2 variant are structurally related but not identical proteins.

Patient erythrocyte membranes contain normal binding sites for protein 4.2. To investigate the possibility of a defective 


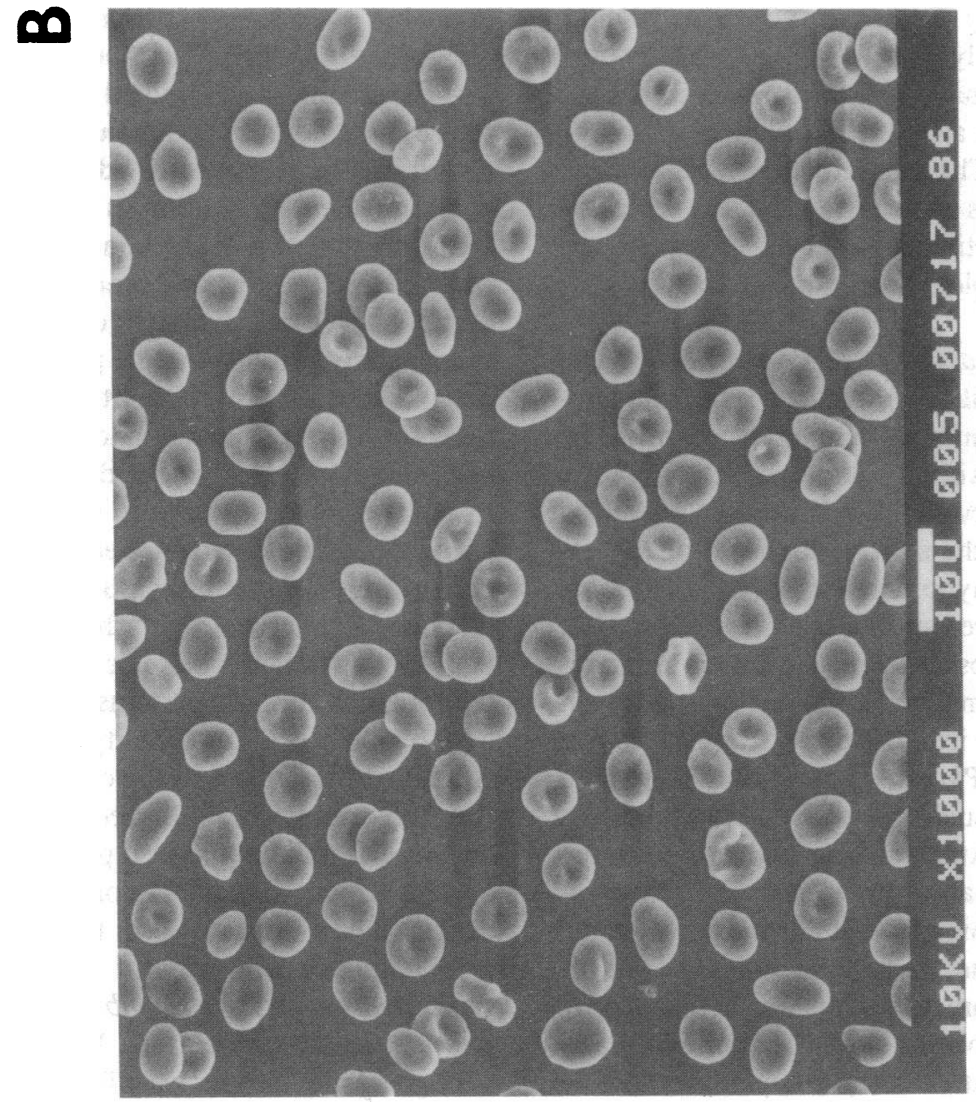

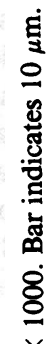

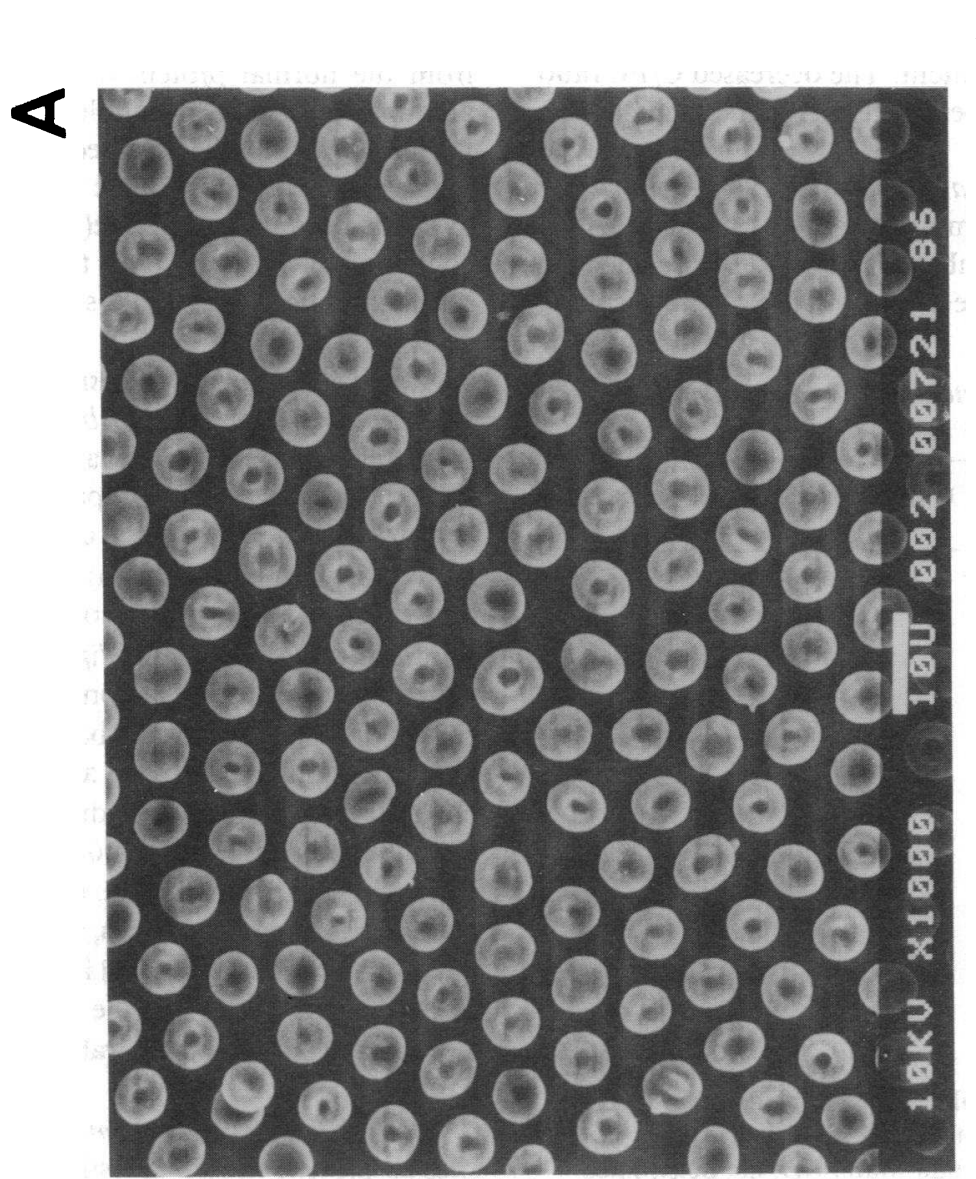

告 


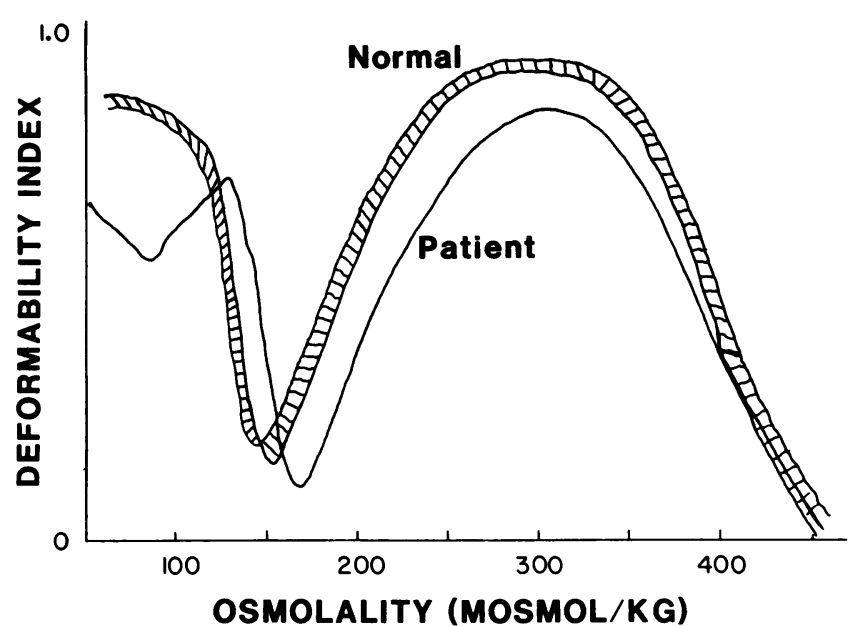

Figure 2. Osmotic gradient ektacytometric scans of normal and patient erythrocytes. The deformability index (DI) was measured at a constant applied shear stress as a continuous function of the suspending medium osmolality (mosmol $/ \mathrm{kg}$ ). The shaded area represents the normal range. In the patient, the curve minimum is shifted to the right and the maximum DI is decreased indicating an increase in osmotic fragility and a loss of membrane surface area.

membrane binding site for protein 4.2 in the patient membranes, normal and patient pH 11.0 extracted (protein 4.2stripped) IOVs were reassociated with purified normal protein 4.2. The amount of protein 4.2 rebinding was similar, indicating that the patient's membranes had a normal complement of protein 4.2 binding sites (Fig. $7 \mathrm{~A}$ ). Scatchard analysis of the rebinding data indicated that both normal and patient membranes had a maximal protein 4.2 binding capacity of 180 $\mu \mathrm{g} / \mathrm{mg}$ band 3 that is equivalent to 1 protein 4.2 monomer $/ 4$ band 3 monomers (Fig. $7 \mathrm{~B}$ ). This calculated stoichiometry is similar to the ratio of protein 4.2 to band 3 measured in erythrocyte membranes (1 protein 4.2 monomer/3.9 band 3 monomers) (24).

Decreased association of ankyrin with the membrane in spectrin-depleted patient IOVs. When spectrin and actin were extracted from the protein 4.2-deficient ghost membranes, most of the ankyrin was also lost from the membrane and recovered in the low ionic strength supernatant. By contrast, in normal membranes ankyrin is completely retained on the membrane under these conditions (Fig. 8). Since a normal amount of ankyrin is present on the patient ghost membranes this suggests that only under conditions that remove spectrin and actin does the ankyrin-membrane interaction become un-

Table II. Membrane Lipid Content and Cholesterol/Phospholipid Ratio of Normal and Protein 4.2-deficient Erythrocytes

\begin{tabular}{lcl}
\hline & Normal range & \multicolumn{1}{c}{$\begin{array}{c}\text { Protein 4.2-deficient } \\
\text { patient* }\end{array}$} \\
\hline Cholesterol (C) & $3.9-4.3 \mathrm{mM}$ & $3.4 \mathrm{mM}$ \\
Phospholipid (PL) & $4.3-4.8 \mathrm{mM}$ & $4.0 \mathrm{mM}$ \\
C/PL ratio & $0.89-1.01$ & 0.86
\end{tabular}

* Protein 4.2-deficient values are presplenectomy.

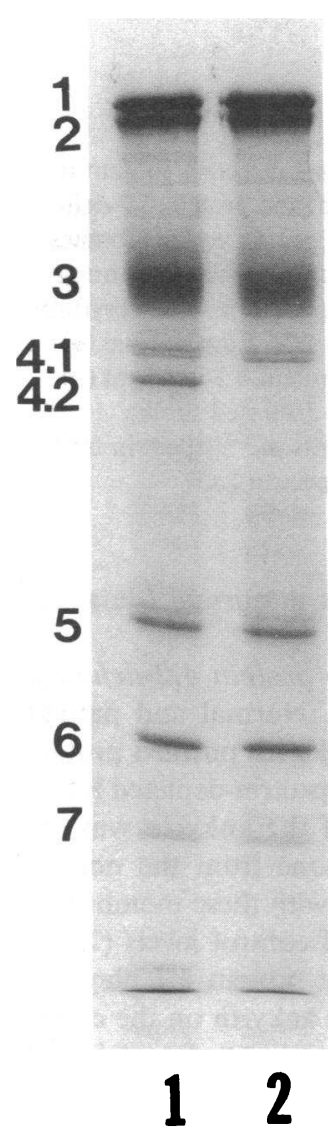

Figure 3. Protein composition of normal and patient erythrocyte ghost membranes. $20 \mu \mathrm{g}$ each of normal ghost membrane proteins (lane 1 ) and patient ghost membrane proteins (lane 2) were separated on 9\% Laemmli SDS-PAGE.

stable in the patient's membranes. To determine if a decrease in the number of ankyrin membrane binding sites was responsible for the loss of ankyrin from the patient IOVs, normal purified ankyrin was reassociated with normal and patient ankyrin-stripped IOVs. Similar ankyrin binding was obtained using either IOVs suggesting that the number of ankyrin bind-

Table III. Characterization of Normal and Protein 4.2-deficient Erythrocyte Ghost Membrane Proteins

\begin{tabular}{lccc}
\hline & & \multicolumn{2}{c}{ Protein 4.2-deficient } \\
\cline { 3 - 4 } \multicolumn{1}{c}{ Protein band } & Normal & Presplenectomy & Postsplenectomy \\
\hline 1 ( $\alpha$ spectrin) & $21 \pm 3$ & $20 \pm 11$ & $21 \pm 2$ \\
$2+2.1(\beta$ spectrin & & & \\
$\quad+$ ankyrin) & $20 \pm 3$ & $21 \pm 7$ & $20 \pm 3$ \\
3 & $37 \pm 2$ & $33 \pm 3^{*}$ & $30 \pm 5^{*}$ \\
4.1 & $5 \pm 1$ & $5 \pm 2$ & $5 \pm 1$ \\
4.2 & $5 \pm 1$ & $<0.5^{\ddagger}$ & $<0.5^{\ddagger}$ \\
5 (actin) & $7 \pm 3$ & $7 \pm 3$ & $7 \pm 2$ \\
6 (G3PD) & $3 \pm 2$ & $5 \pm 1^{\ddagger}$ & $5 \pm 1^{\ddagger}$ \\
7 & $2 \pm 1$ & $2 \pm 1$ & $3 \pm 1$
\end{tabular}

Results are expressed as percent of total peak areas from densitometric scans of 9\% Laemmli SDS-PAGE. Mean \pm 1 SD of 9-15 determinations.

* Differs from normal at $P<0.01$.

₹ Differs from normal at $P<0.001$. 


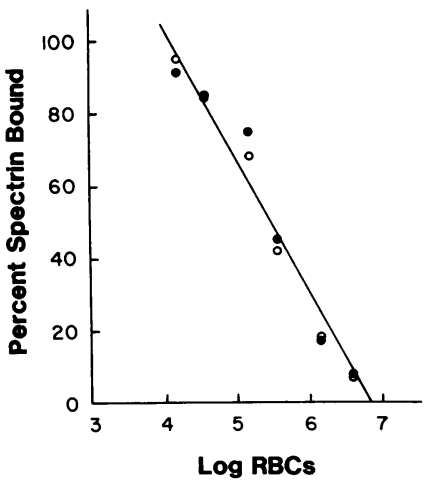

Figure 4. Spectrin content of normal and protein 4.2-deficient erythrocyte membranes measured by radioimmunoassay. Spectrin in whole erythrocyte lysates from normal (•) and protein 4.2-deficient $(0)$ blood displaced similar amounts of ${ }^{125} \mathrm{I}$-spectrin from anti-spectrin IgG.

ing sites on the patient's membranes is normal (data not shown).

Effect of rebinding protein 4.2 to protein 4.2-deficient membranes on ankyrin extractability. Normal and patient leaky ghost membranes were incubated with purified protein 4.2 and then resealed before preparing spectrin-depleted IOVs. Whereas approximately two-thirds of the ankyrin was extracted from the patient IOVs (but none from the normal IOVs), the reassociation of protein 4.2 with these membranes restored ankyrin binding to $\sim 80 \%$ of control levels (Table IV). These results strongly suggest that protein 4.2 plays an important functional role in stabilizing ankyrin on the erythrocyte membrane. We found that the amount of protein 4.2 that could bind to either the normal or protein 4.2-deficient leaky ghost membranes was considerably greater than that normally found in the native membrane (Fig. 9), possibly reflecting binding to low affinity sites reported by Korsgren and Cohen (21).

\section{Discussion}

The identification of pathologic erythrocytes that are deficient in specific membrane proteins, or whose membranes contain

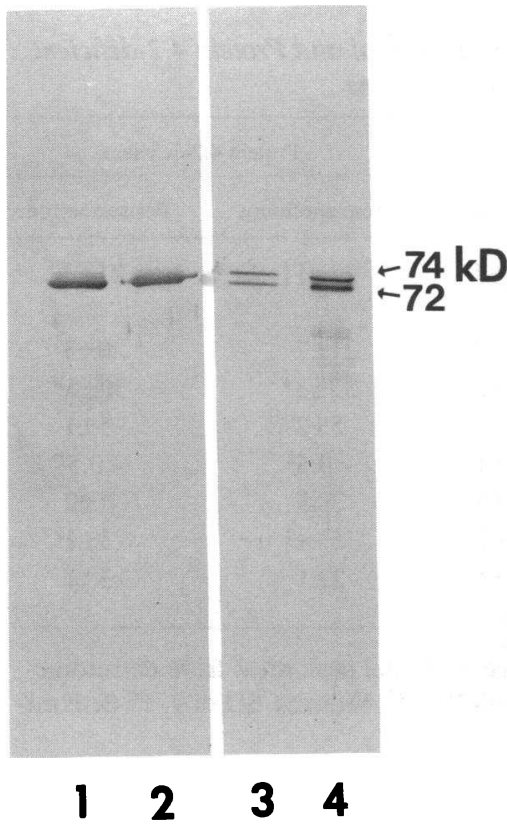

Figure 5. Immunoblot of normal and patient ghost membrane proteins. Normal ghost membranes (lane 1 ), pH 11.0 extract of normal ghost membranes (lane 2), patient ghost membranes (lane 3), and $\mathrm{pH} 11.0$ extract of patient ghost membranes (lane 4). The proteins $(20 \mu \mathrm{g})$ were separated on $9 \%$ Laemmli SDS-PAGE, transferred to nitrocellulose and developed with affinity purified anti-protein $4.2 \mathrm{IgG}$.

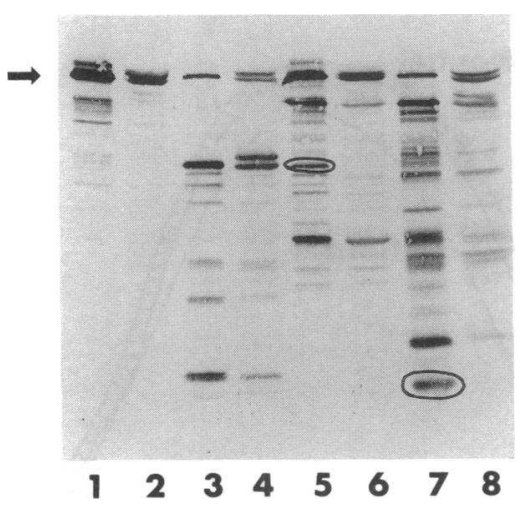

Figure 6. Immunoblot of protease-digested normal and patient IOV membranes. The proteins were separated on 9\% Laemmli SDSPAGE, transferred to nitrocellulose and developed with anti-protein 4.2 IgG. Normal IOVs (lane 1 ) were digested with $1 \mu \mathrm{g}$ trypsin (lane 3), $1 \mu \mathrm{g} \alpha$-chymotrypsin (lane 5) or 0.33 $\mu \mathrm{g}$ papain (lane 7). $\mathrm{Pa}$ tient IOVs (lane 2) were similarly digested with trypsin (lane 4), $\alpha$ chymotrypsin (lane 6) or papain (lane 8). Protein bands in the normal digests not observed in the patient digests are circled. Arrow, position of undigested protein 4.2 .

functionally abnormal proteins, has been a valuable tool in the elucidation of protein structural/functional roles. For example, certain forms of hemolytic anemias such as hereditary spherocytosis (HS), hereditary elliptocytosis (HE), and hereditary pyropoikilocytosis (HPP) have been shown to be related to the deficiency or abnormal function of specific membrane proteins $(2-5,25)$. In the present study, a patient with hemolytic anemia was identified whose erythrocytes were $>90 \%$ deficient of protein 4.2. Since little is known regarding the function of protein 4.2 , we investigated the membrane properties of these protein 4.2-deficient membranes to determine if any structural/functional abnormalities resulted from the absence of this protein.

Several investigators have reported that protein 4.2 was absent or reduced in certain cases of $\operatorname{HS}(26,27)$. However, no

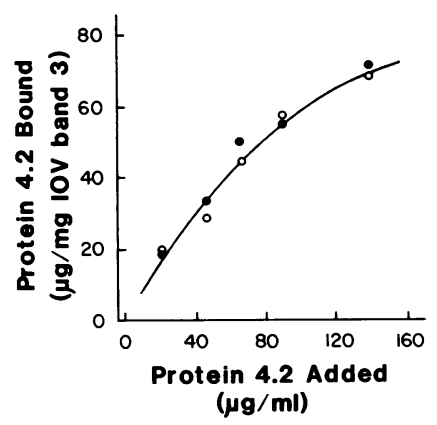

A

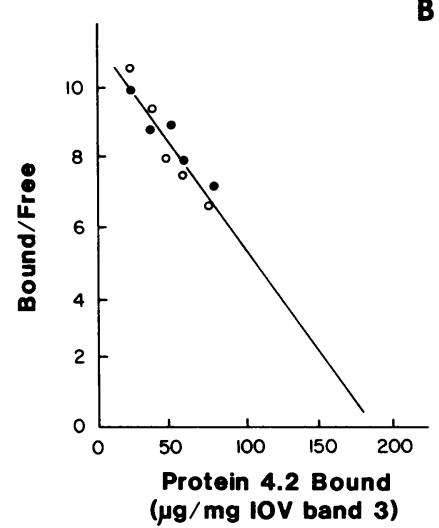

Figure 7. (A) Binding of ${ }^{125} \mathrm{I}-$ protein 4.2 to protein $4.2-$ stripped (pH 11.0 extracted) IOVs. ${ }^{125}$ I-protein 4.2 was incubated with protein 4.2 stripped normal (๑) and patient (o) IOVs ( $20 \mu \mathrm{g}$ protein) for $18 \mathrm{~h}$ at $4^{\circ} \mathrm{C}$, followed by collection of the IOVs by centrifugation, washing, and counting to determine the amount of protein 4.2 bound to the membrane. $(B)$ Scatchard analysis of data from $A$. 

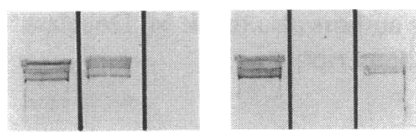

123456
Figure 8. Immunoblot of ankyrin in normal and patient IOVs and low ionic strength supernatants. Normal (lane 1) and patient (lane 4) ghost membranes were incubated in low ionic strength buffer $(0.1$

$\mathrm{mM}$ Tris $\mathrm{HCl}, \mathrm{pH} 8.0$ ) to induce vesiculation followed by collection of the IOVs by centrifugation. Normal IOVs (lane 2), normal low ionic strength supernatant (lane 3), patient IOVs (lane 5) and low patient ionic strength supernatant (lane 6) proteins were separated on 9\% Laemmli SDS-PAGE, transferred to nitrocellulose and developed with anti-ankyrin IgG. Each lane contained $20 \mu \mathrm{g}$ protein.

correlation was found between the degree of protein 4.2 deficiency and the severity of the disease. The patient described in this study presented with a mild Coombs negative hemolytic anemia with an abnormal erythrocyte morphology (spherocytic and elliptocytic shaped cells), increased osmotic fragility and decreased membrane deformability. Each of these criteria by themselves is consistent with a diagnosis of HS, however, in contrast to typical HS, where a decrease in the amount of spectrin is usually found, the patient's erythrocytes had a normal amount of spectrin as determined both by electrophoretic analysis and by RIA. Furthermore, SDS-PAGE analysis of the patient's membranes revealed that only protein 4.2 was missing from the membrane. The small but statistically significant reduction in band 3 probably reflects a loss of membrane surface area due to vesiculation, and is consistent with the abnormal osmotic fragility and deformability of these membranes. The reason for the increased amount of band 6 is not clear at this time.

In addition to an abnormal cell morphology, cholesterol/ phospholipid ratio, and osmotic fragility that persisted in the patient's erythrocytes postsplenectomy, the deficiency of protein 4.2 in these cells also remained postsplenectomy. This is different from some other cases of protein 4.2 deficiency that have been reported where the missing protein reappeared after correction of the primary pathology. For example, in erythrocytes from patients with obstructive jaundice where a partial deficiency of protein 4.2 was reported, the erythrocyte content

Table IV. Effect of Protein 4.2 on the Association of Ankyrin with Erythrocyte Membranes

\begin{tabular}{llcc}
\hline Membrane source & \multicolumn{1}{c}{ Membrane } & Protein 4.2/band 3 & Ankyrin/band 3 \\
\hline Normal & Ghost & $0.15 \pm 0.02$ & $0.15 \pm 0.02$ \\
erythrocytes & IOV & $0.16 \pm 0.01$ & $0.16 \pm 0.03$ \\
& 4.2-repleted IOV & $0.73 \pm 0.04$ & $0.14 \pm 0.02$ \\
Protein 4.2-deficient & Ghost & $0.02 \pm 0.01^{*}$ & $0.16 \pm 0.04$ \\
erythrocytes & IOV & $0.01 \pm 0.01^{*}$ & $0.06 \pm 0.01^{*}$ \\
& 4.2-repleted IOV & $0.81 \pm 0.05$ & $0.11 \pm 0.02$ \\
\hline
\end{tabular}

Normal and patient protein 4.2-deficient leaky ghosts (165 $\mu \mathrm{g}$ ) were reconstituted with either $5 \mathrm{mM}$ sodium phosphate, $\mathrm{pH} 8.0$, or $35 \mu \mathrm{g}$ purified normal protein 4.2 before resealing. IOVs were then prepared from these resealed ghosts (4.2-repleted IOVs) as described in Methods. Membrane proteins (20 $\mu \mathrm{g})$ were then separated on $3.5 \rightarrow 15 \%$ Fairbanks linear polyacrylamide gradient gels and the results (mean \pm 1 SD) of six determinations are expressed as ratios of the protein band areas determined from densitometric scans.

* Differs from normal at $P<0.001$.

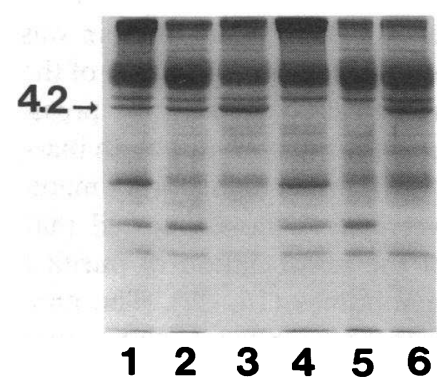

Figure 9. Normal and patient leaky ghost membranes reconstituted with purified protein 4.2. Normal (lane 1 ) and patient (lane 4) leaky ghosts were reconstituted with purified protein 4.2 followed by preparation of spectrin-depleted IOVs. Normal IOVs (lane 2), normal IOVs prepared from protein 4.2 reconstituted normal ghosts (lane 3), patient

IOVs (lane 5) and IOVs prepared from protein 4.2 reconstituted patient ghosts (lane 6) were analyzed on 9\% Laemmli SDS-PAGE. Each lane contained $20 \mu \mathrm{g}$ protein.

of the protein was found to be normal following surgical removal of the obstruction (28).

Erythrocytes from the patient's parents were found to be normal in the content of protein 4.2 as well as by all other criteria measured in our studies. Since we have not yet been able to study erythrocytes of the patient's siblings we do not know whether this defect was inherited or represented some other acquired abnormality such as a point mutation in the protein 4.2 gene or a defect in some as yet unidentified processing enzyme required for protein 4.2 biogenesis. Further studies are in progress to examine the etiology of the protein 4.2 deficiency in this patient.

When immunoblots of the patient's erythrocyte membranes were probed with an affinity purified antibody against normal protein 4.2 , we found that the membranes contained a small amount of a protein 4.2 immunolog $(<10 \%$ of normal protein 4.2). This immunolog varied from the normal protein in that it was composed of equal amounts of a 74- and 72-kD protein doublet, whereas the normal protein was composed predominantly of a $72-\mathrm{kD}$ monomer. The protein $4.2 \mathrm{im}$ munolog appeared to be structurally similar to the normal protein since both proteins had similar proteolytic digestion patterns using trypsin, $\alpha$-chymotrypsin, and papain. However, the protein 4.2 immunolog is not structurally identical to the normal protein since the $\alpha$-chymotrypsin and papain digests of the normal protein contained at least one major protein band not seen in the protein 4.2 immunolog digests. The protein 4.2 immunolog appeared to associate with the erythrocyte membrane normally since it was extracted from the membrane only under harsh conditions ( $\mathrm{pH} 11.0$ ), similar to the normal protein. Preliminary experiments in our laboratory suggest that a protein 4.2 immunolog similar to the one in the patient's erythrocytes is also found in the patient's leukocytes, and is present in reduced amounts compared to normal leukocytes.

Clues as to a possible function of protein 4.2 came from studies examining the association of ankyrin with spectrin-depleted IOV membranes. Whereas in normal membranes the extraction of spectrin and actin by low ionic strength buffers does not result in a loss of ankyrin, in the protein 4.2-deficient membranes $\sim 70 \%$ of the ankyrin was extracted by low ionic strength buffer. Furthermore, reassociation of purified protein 4.2 to the protein 4.2-deficient membranes partially prevented the extraction of ankyrin at low ionic strength. These results suggest that one function of protein 4.2 is to stabilize or modulate interactions of ankyrin with its high affinity binding site 
on the membrane. That a large amount of added protein was required to generate this effect would suggest that not all of the reconstituted protein was assembled properly into the preassembled membrane cytoskeletons. This may be due to an inaccessibility of all of the added protein for its high affinity membrane binding sites. Other investigators have reported that protein 4.2 is not necessary for the reassociation of purified ankyrin to ankyrin-stripped membranes $(16,29)$. The data presented in this study differs from these other studies in that we evaluated the loss of ankyrin from membranes and not the reassociation of purified ankyrin with ankyrin-stripped membranes. The procedures used to dissociate ankyrin from the membrane may affect the ankyrin binding site and/or alterations in ankyrin induced by its purification may also affect its membrane rebinding properties. Since a normal amount of ankyrin is present in the protein 4.2-deficient ghost membranes, this suggests that the ankyrin binding site is normal in these membranes. We hypothesize that the interaction of ankyrin with its high affinity membrane binding site on band 3 is weakened in the absence of protein 4.2 , and in the absence of stabilizing interactions with spectrin and actin, the ankyrin dissociates from the membrane. Further studies will be necessary to determine the molecular basis for the apparent stabilizing effect of protein 4.2 on ankyrin-band 3 interactions.

In summary, we have identified and characterized a Coombs negative hemolytic anemia associated with a $>90 \%$ deficiency of protein 4.2. These erythrocytes are morphologically abnormal and mechanically unstable. They exhibit many of the same characteristics as typical HS erythrocytes except that the spectrin content of the protein 4.2-deficient cells is normal. Although splenectomy corrected the patient's anemia, the deficiency of protein 4.2 persisted as did the abnormal erythrocyte morphology, osmotic fragility and membrane mechanical properties. This would suggest that the absence of protein 4.2 somehow led to a membrane abnormality that was recognized by the spleen that removed these cells from the circulation. The precise molecular relationship between the deficiency of protein 4.2 and the membrane abnormality/hemolytic anemia remains unclear. That ankyrin may be involved is suggested by the decreased affinity of ankyrin for its membrane attachment site in the protein 4.2-deficient spectrin-depleted membranes, which was partially corrected by repletion of these membranes with purified protein 4.2. Further studies are needed to determine whether the protein 4.2 deficiency and the anemia are causally related, and to determine whether the molecular properties of the protein 4.2 variant observed in the protein 4.2-deficient membranes differ functionally from the normal protein. It should be noted that Hayashi et al. (26) observed the complete absence of protein 4.2 in 4 of 15 cases of HS they studied, and a decreased amount of the protein in all of the other cases. This suggests that protein 4.2 deficiency may not be a rare pathology, and further suggests that the absence or deficiency of this protein may be a component in the molecular mechanisms underlying some forms of $\mathrm{HS}$.

\section{Acknowledgments}

The authors are grateful to Dr. P. Agre for performing some of the spectrin radioimmunoassays, Dr. J. Bastacky for providing the scanning electron micrographs and $\mathrm{K}$. Kleman for performing the osmotic fragility tests and ektacytometry. The authors also thank M. Douglass and $\mathbf{P}$. Ross for preparation of the manuscript.

\section{References}

1. Goodman, S. R., and K. Shiffer. 1983. The spectrin membrane skeleton of normal and abnormal human erythrocytes. A review. Am. J. Physiol. 244:C121-C141.

2. Agre, P., J. F. Casella, W. H. Zinkham, C. McMillan, and V. Bennett. 1985. Partial deficiency of erythrocyte spectrin in hereditary spherocytosis. Nature (Lond.). 314:380-383.

3. Wolfe, L. C., K. M. John, J. C. Falcone, A. M. Byrne, and S. E. Lux. 1982. A genetic defect in the binding of protein 4.1 to spectrin in a kindred with hereditary spherocytosis. N. Engl. J. Med. 307:13671374.

4. Tchernia, G., N. Mohandas, and S. B. Shohet. 1981. Deficiency of skeletal membrane protein 4.1 in homozygous hereditary elliptocytosis: implications for red cell membrane stability. J. Clin. Invest. 68:454-460.

5. Liu, S. C., J. Palek, and J. T. Prchal. 1982. Defective spectrin dimer-dimer association in hereditary elliptocytosis. Proc. Natl. Acad. Sci. USA. 79:2072-2076.

6. Yu, J., and T. L. Steck. 1975. Associations of band 3, the predominant polypeptide of the human erythrocyte membrane. J. Biol. Chem. 250:9176-9184.

7. Steck, T. L. 1972. Crosslinking of the major proteins of the isolated erythrocyte membrane. J. Mol. Biol. 66:295-305.

8. Bennett, V., and P. J. Stenbuck. 1979. The membrane attachment protein for spectrin is associated with band 3 in human erythrocyte membranes. Nature (Lond.). 280:468-473.

9. Dacie, J. V., and S. M. Lewis. 1975. In Practical Hematology (Fifth Edition) Churchill Livingston, New York. 202.

10. Mohandas N., M. R. Clark, M. S. Jacobs, and S. B. Shohet. 1980. Analysis of factors regulating erythrocyte deformability. J. Clin. Invest. 66:563-573.

11. Rose, H. G., and M. Oklander. 1965. Improved procedures for the extraction of lipids from human erythrocytes. J. Lipid Res. 6:428431.

12. Zlatkis, A., B. Zak, and A. J. Boyle. 1953. A new method for direct determination of serum cholesterol. J. Lab. Clin. Med. 41:486492.

13. Bartlett, G. R. 1959. Phosphorus assay in column chromatography. J. Biol. Chem. 234:466-468.

14. Dodge, J. T., C. Mitchell, and D. J. Hanahan. 1963. The preparation and chemical characteristics of hemoglobin free ghosts of the human erythrocyte. Arch. Biochem. Biophys. 100:119-130.

15. Bennett, V., and D. Branton. 1977. Selective association of spectrin with the cytoplasmic surface of human erythrocyte plasma membrane: quantitative determination with purified $\left[{ }^{32} \mathrm{P}\right]$ spectrin. $J$. Biol. Chem. 252:2753-2763.

16. Hargreaves, W. R., K. N. Giedd, A. Verkleij, and D. Branton. 1980. Reassociation of ankyrin with band 3 on erythrocyte membranes and lipid vesicles. J. Biol. Chem. 255:11965-11972.

17. Tyler, J. M., B. N. Reinhardt, and D. Branton. 1980. Associations of erythrocyte membrane proteins: binding of purified bands 2.1 and 4.1 to spectrin. J. Biol. Chem. 255:7034-7039.

18. Laemmli, U. K. 1970. Cleavage of structural proteins during the assembly of the head of bacteriophage T4. Nature (Lond.). 227:680-685.

19. Fairbanks, G., T. L. Steck, and D. F. H. Wallach. 1971. Electrophoretic analysis of the major polypeptides of the human erythrocyte membrane. Biochemistry. 10:2606-2617.

20. Towbin, H., T. Stachelin, and J. Gordon. 1979. Electrophoretic transfer of proteins from polyacrylamide gels to nitrocellulose sheets: procedures and some applications. Proc. Natl. Acad. Sci. USA 76:4350-4354. 
21. Korsgren, C., and C. M. Cohen. 1986. Purification and properties of human erythrocyte band 4.2. J. Biol. Chem. 261:5536-5543.

22. Bolton, A. E., and W. M. Hunter. 1973. The labelling of proteins to high specific radioactivities by conjugation to ${ }^{125} I$ containing acylating agents. Biochem. J. 133:529-538.

23. Scatchard, G. 1949. The attractions of proteins for small molecules and ions. Ann. N.Y. Acad. Sci. 51:660-675.

24. Steck, T. L. 1974. The organization of proteins in the human red blood cell membrane. J. Cell Biol. 62:1-19.

25. Palek, J., S. C. Liu, P. Y. Liu, and R. P. Castleberry. 1981. Altered assembly of spectrin in red cell membranes in hereditary pyropoikilocytosis. Blood. 57:130-138.

26. Hayashi, S., R. Kosmato, A. Yano, S. Ishigami, G. Tsujino, S.
Saeki, and T. Tanaka. 1974. Abnormality in a specific protein of the erythrocyte membrane in hereditary spherocytosis. Biochem. Biophys. Res. Commun. 57:1038-1044.

27. Nozawa, Y., T. Hoguchi, H. Iida, H. Fukushima, T. Sekiya, and Y. Ito. 1974. Erythrocyte membranes of hereditary spherocytosis: alterations in surface ultrastructure and membrane proteins as inferred by scanning electron microscopy and SDS gel electrophoresis. Clin. Chem. Acta. 55:81-85.

28. Iida, H., I. Hasegawa, and Y. Nozawa. 1976. Biochemical studies on abnormal erythrocyte membranes. Biochim. Biophys. Acta. 443:394-401.

29. Bennett, V., and P. J. Stenbuck. 1980. Association between ankyrin and the cytoplasmic domain of band 3 isolated from the human erythrocyte membrane. J. Biol. Chem. 255:6424-6432. 